\title{
اختلاف مترجمى القرآن الكريم في مقابلة أحرف مصدرية
}

\author{
Yulius Mas'ud \\ UIN Imam Bonjol Padang \\ yuliusmas'ud@uinib.ac.id
}

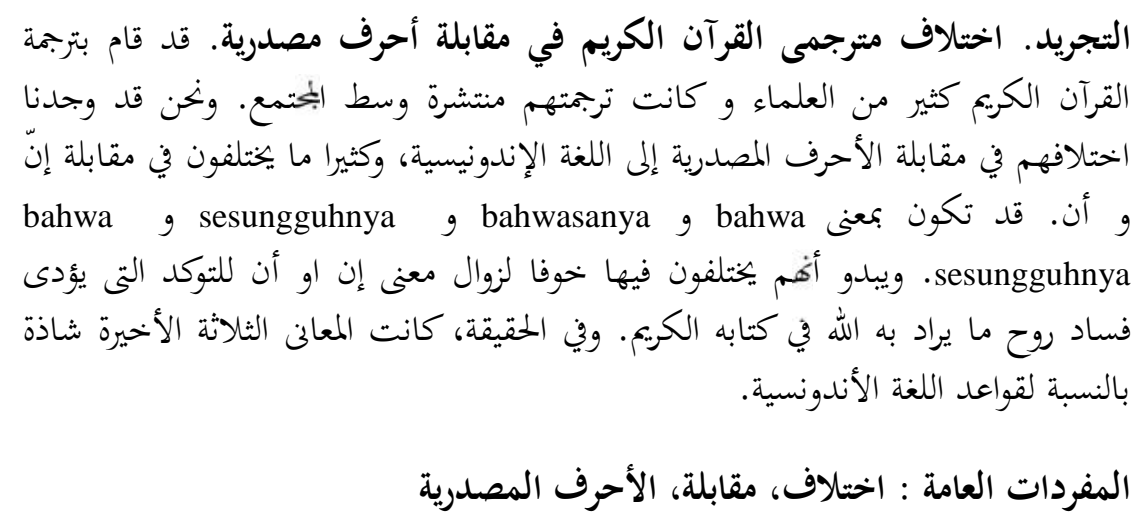

\begin{abstract}
Abstrak. Perbedaan Para Penerjemah al-Quran dalam Memahami Huruf Mashdariyah. Penerjemahan al-Quran telah dilakukan oleh sebagian besar ulama, yang terjemahan mereka tersebar luas di dalam masyarakat.Mereka sering berbeda dalam memahami huruf mashdariyah ketika huruf tersebut diterjemahkan ke dalam Bahasa Indonesia dan mereka sering berbeda pendapat dalam mencari padanan kata إن dalam bahasa Indonesia seperti : bahwa, bahwasanya, sesungguhnya dan bahwa sesungguhnya. Kelihatannya, perbedaan pendapat mereka dipicu oleh adanya kekhawatiran akan hilangnya ruh bahasa alQur'an yang menekankan adanya makna taukid. Ternyata, tiga makna terakhir juga terasa janggal menurut aturan bahasa Indonesia.
\end{abstract}

\section{Kata kunci: Ikhtilaf, Pemahaman, Huruf Mashdariyah}

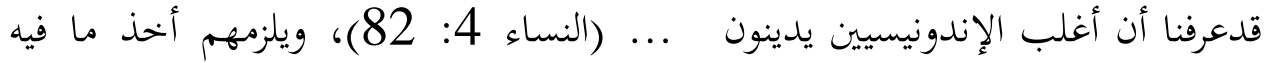

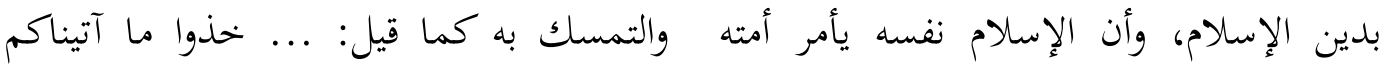

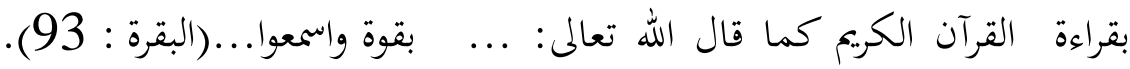

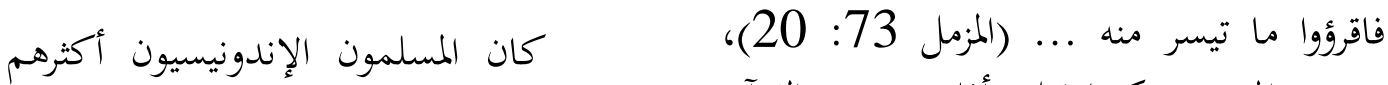

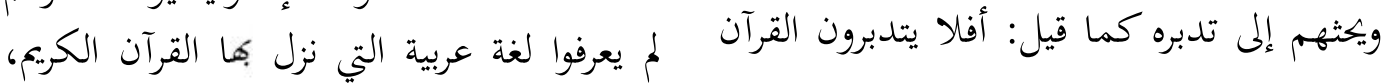


نحن قد وجدنا فرقا واضحا بين الكلمات السابقة في اللغة الإندونيسيية، كانت فرأت كلمة

konjungsi "bahwa"

bahwasanya / أم subordinatif

konjungsi تسمى sesungguhnya .antar kalimat

"Konjungsi subordinat adalah konjungsi yang menghubungkan dua klausa atau lebih dan klausa itu tidak memiliki status sintaksis yang sama. Salah satu dari klausa itu merupakan anak kalimat dari kalimat induknya.

Contoh: Pendidikan Sistem Eropa mengajarkan kepada sastrawan bahwa sastra tidak harus sepenuhnya dikaitkan pada dunia keagamaan. ${ }^{4}$

"Konjungsi antar kalimat menghubungkan satu kalimat dengan kalimat yang lain. Karena itu, konjungsi macam itu selalu memulai suatu kalimat yang baru dan tentu saja huruf pertamanya ditulis dengan huruf kapital.

Contoh: Masalah yang dihadapinya memang gawat. Sesungguhnya masalah itu sudah diramalkan sebelumnya. ${ }^{5}$

$$
\text { بناء على ما قدمت أعلاه، فالبحث }
$$

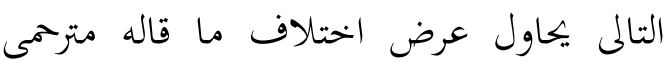

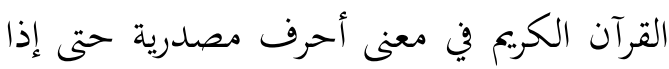

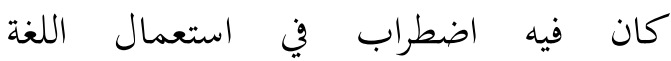

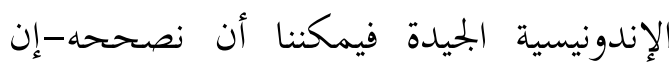

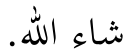

${ }^{4}$ Departemen Pendidikan dan

Kebudayaan RI, Tata Bahasa Baku Bahasa

Indonesia, Jakarta: Balai Pustaka, 1988), hal.

237
مع أفم يريدون أن يفهموا ما فيه من المواعظ

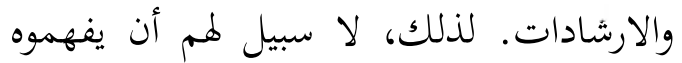

إلا بواسطة ترجمته باللغة الإندونيسية. وبعبارة

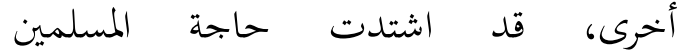

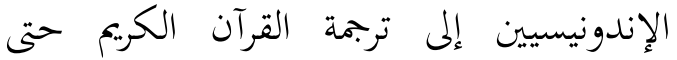

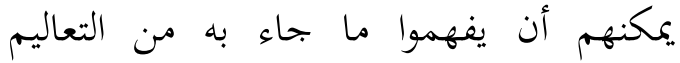
الإسلامية.

قد قام بترجمة القرآن الكريم كثير من

العلماء وكانت هذه الترجمة منتشرة وسط العرائ

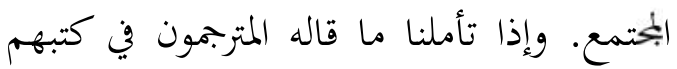
رأينا فيه اختلافهم في مقابلة أحرف مصدراكلنا مارية،

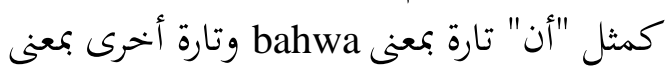
gbahwa sesungguhnyagbahwasanya .sesungguhnya مثلا:

- ....وظن أهلها أفم قارون عليها... (يونس (24:10

“... Dan penduduknya menduga, bahwa mereka dapat menguasainya..."

وكتبنا عليهم فيها أن النفس بالفس والعين

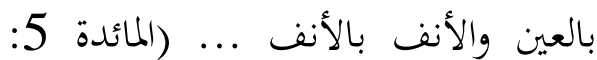
45

"Dan telah kami wajibkan atas mereka di dalamnya bahwasanya jiwa (balas) dengan jiwa, mata dengan mata, hidung dengan hidung..."

$$
\text { - - }
$$

"Dan bahwa sesungguhnya kepada Tuhanmu tempat kesudahannya kembali)..."

$$
\begin{aligned}
& 1 \text { محمد يونس، ترجمة القرآن الكريم، (بندنج: } \\
& \text { المعارف، 1987)، ص. } 191 \\
& \text { Hamka }{ }^{2} \\
& \text { مشاركت، 1982)، ط 2، ج-6، ص. } 293 \\
& 3 \text { محمد يونس، المرجع السابق، ص. }
\end{aligned}
$$




$$
\begin{aligned}
& \text { مثلا + الشاهدان كاذبان. أدركت شيئا. } \\
& \text { ـ ـ أدركت أن الشاهدين كاذبان. }
\end{aligned}
$$

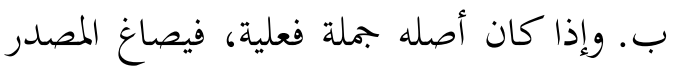

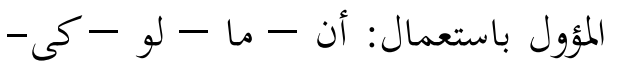

$$
\text { همزة التسوية. }
$$$$
\text { مثلا: }
$$

+ و وأنتم) تعفون. (هو) أقرب للتقوى.

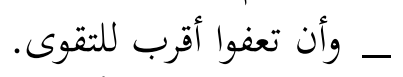

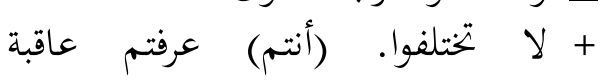
الاختلاف.

- لا لاختلفوا بعد مال عرفتم عاقبة الاختلاف.

+ ومن الذين أشركوا يود أحدهم شيئا. (هو يعمر ألف سنة) أشركوا يود الفي

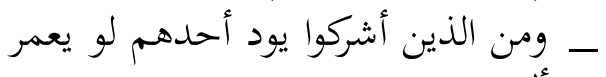
ألف سنة.

+ تقام المنارات. هي) تهدى السفن ليلا.

ـ ـقام المنارات لكى تحدى السفن ليلا.

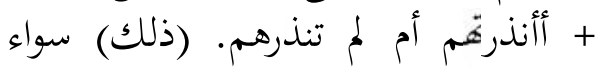

$$
\text { ـ عليهم عليهم أأنذرغم أم الم تنذرهم. }
$$

إنما يجب تأويل ما بعد الأحرف المصدرية

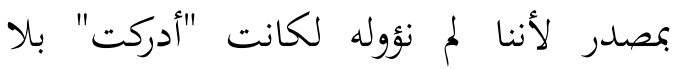
مفعول، و "أقرب" بلا مبتدأ وبعد بلا مضاف لونه

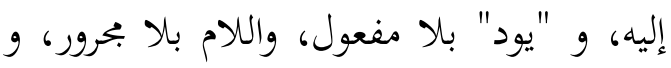
"سواء" في المثال الأخير بلا مبتدأ مؤخر.

مقابلة الأحرف المصدرية في اللغة

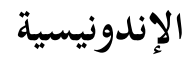

كما قدمت سابقا أن هناك اختلاف مترجمى القرآن الكريم في مقابلة الأحرف

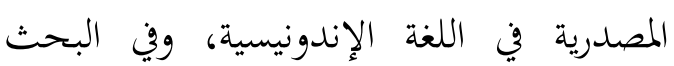

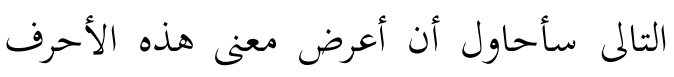

\section{الأحرف المصدرية والمصدر المؤول}

قبل أن نتكلم عن هذا، فلينظر إلى

المثالين التليين،

- ل الا شك في أن الأدب واجب

- ل الا شك في وجوب في الأدب الاب

ففي هذين المثالين رأينا مقابلة بين

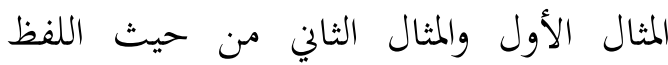

والمعنى، بند أول أنه وضع في الجملة مصدر في المان

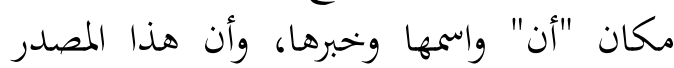

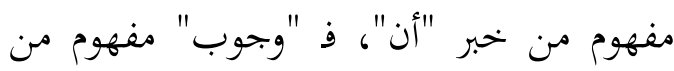

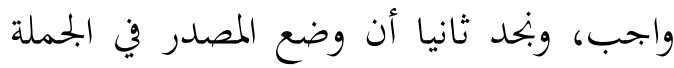

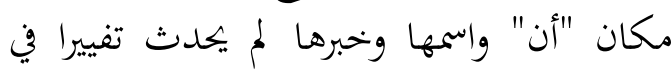
المعنى، فالمثال السابق يتضمن إذا مصدرا مفهوما

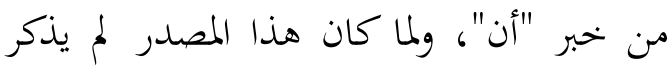

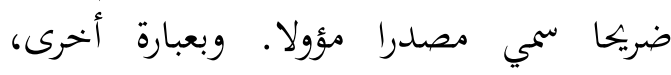

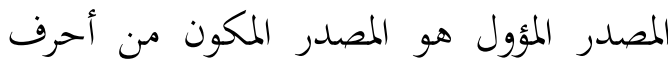

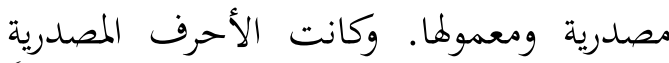
هي: أن- أن- ما- لو -كى - همزة التسوية. 6

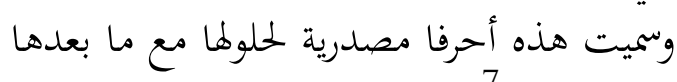
محل المصدر. إذا علمنا ذلك، فلننظر أيضا صوغ

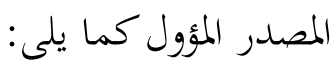
أ. يصاغ المصدر المؤول بـ "أن" إذا كان أصله

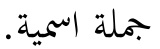

$$
\begin{aligned}
& 6 \text { انظر: عبد العليم إبراهيم، النحو الوظيفى، (مصر: }
\end{aligned}
$$

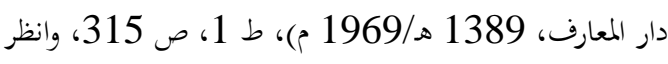

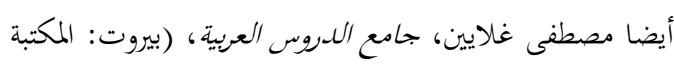

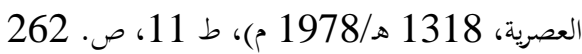

$$
\begin{aligned}
& 7 \text { حفنى بك ناصف وآخرون، قواعد اللغة العربية، } \\
& \text { مصر : ورارة المعارف العمومية)، ص. } 22
\end{aligned}
$$


- ينتظر أن يزيد إنتاجنا الصناعى (كان المصدر المؤول نائب فاعل).

- يريد الله أن يخفف عنكم (كان نائ فاعل).

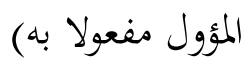

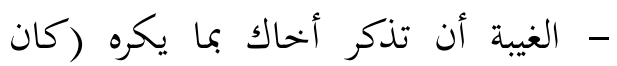

$$
\text { المصدر المؤول خبرا) }
$$

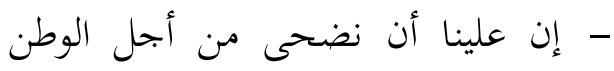

(كان المصدر المؤول اسم إن مؤخر).

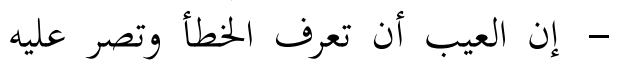

$$
\text { (كان المصدر المؤول خحبر إن). }
$$

- فكر قبل أن تنطق (كان المصدر المؤول المول

$$
\text { مضافا إليه). }
$$

"to" إن مقابلة "أن" في اللغة الإبحليزية في أو أو أو

"The Infinitive phrase may function not only as the main verb of a clause, but either as a noun or adverb". 11

$$
\text { يمكننا أن نقول باللغة الإنجيلزية. }
$$

- To fast (in Ramadhan) is better for you

- That you fast (in Ramadhan) is better for you

$$
\begin{aligned}
& \text { ج. "ما المصدرية" قسمان: وقتية وغير وقتية. } \\
& \text { فالوقتية هي التي تقدر بمصدر نائب عن وعن وفئ وفيه } \\
& \text { ظرف الزمان، نخو: فئي التي }
\end{aligned}
$$

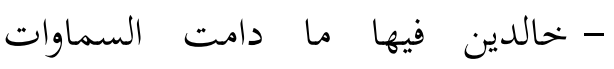

$$
\begin{aligned}
& \text { والأرض (أى مدة دوام السماوات } \\
& \text { والأرض). }
\end{aligned}
$$

${ }^{11}$ N. Krishnaswamy, op. cit., hal. 248
في اللغة الإندونيسية حتى يسهل لنا أن نعرف

ذلك الاختلاف.

أ. "أن" أن تكون هي بمعنى bahwa وتسمى ألفى

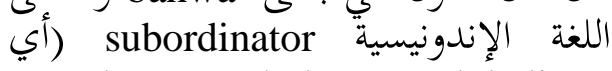

(kata penghubung anak kalimat

“....Klausa sematan menjelaskan apa yang dinyatakan oleh klausa utama. Subordinator yang sering dipakai adalah bahwa." 8

قد تكون كلمة bahwa مخذوفة في

$$
\text { اللغة الإندونيسية }
$$

"Jika susunan kalimat cukup terang, kata peng-hubung bahwa menjadi mana-suka". 9

Contoh: Duta besar itu mene-kankan (bahwa) pemerin-tahannya akan membantu peningkatan kesejahteraan ma-syarakat pedesa-an.

"The conjunction that is frequently omitted when that clause is the object". 10

e.g. I told her (that) she was wrong.

ب. "أن" وهي أن تكون بمنزلة "أن المصدرية"

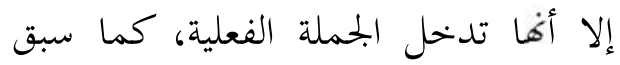

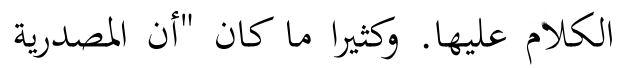

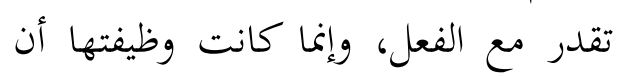
تغير تركيب الجملة الفعلية إلى المصدر

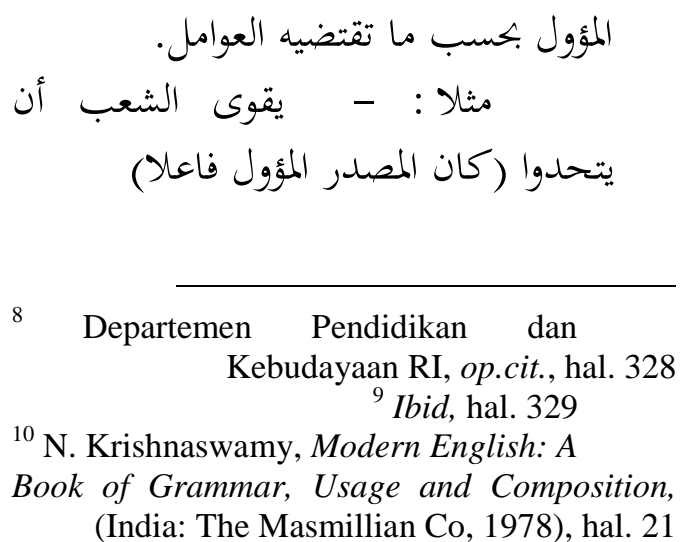




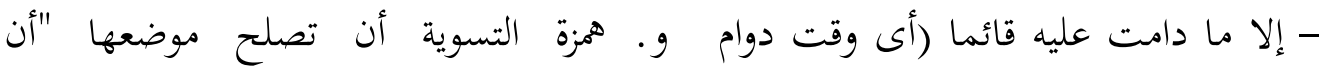

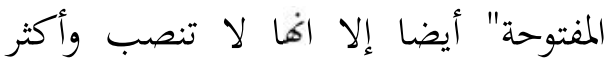

وقوعها بعد "سواء"، نهو: سواء إلاء علينا

وأما غير الوقتية هي التى تقدر

$$
\text { أجزعنا أم صبرنا (أى جزوعنا وصواء كيرنا). }
$$

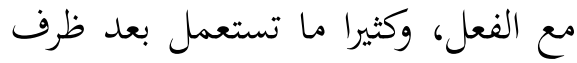

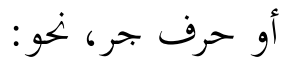

اختلاف المفسرين في مقابلة أحرف مصدرية

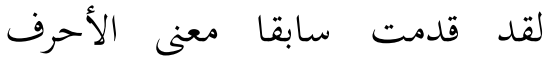

- فذوقوا بما نسيتم لقاء يومكرة

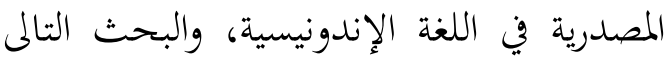
سيحاول عرض ما قاله المترجمون في كتتبهرم منها ما يأتى:

\section{1. الاختلاوف في معنى "أن" أني"}

أ) أولم يكفهم أنا أنزلنا عليك الكي الكتاب

$$
\text { قال محمود يونس: (العنكبوت 29: 51 }
$$

"Dan apakah tiada cukup bagi mereka, bahwa Kami telah menurunkan Kitab kepadamu...."14

$$
\text { قيل في "القرآن وترجمته": }
$$

"Dan apakah tidak cukup bagi mereka bahwasanya Kami telah menurunkan kepadamu Al-Kitab (Al-Qur'an)..."

$$
\begin{aligned}
& \text { ب) ألم تر أن الله يعلم ما في السموات }
\end{aligned}
$$

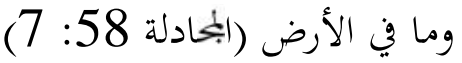

$$
\begin{aligned}
& \text { قال محمود يونس: }
\end{aligned}
$$

"Tiadakah engkau ketahui, bahwa Allah mengetahui apa yang ada di langit dan apa-apa yang ada di bumi?"

$$
\text { قيل في "القرآن وترجمته": }
$$

$$
\begin{aligned}
& 14 \text { محمود يونس، المرجع السابق، ص. } 489
\end{aligned}
$$

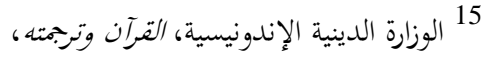

$$
\begin{aligned}
& \text { (جاكرتا: يمونو: 1971)، ص. } 636 \\
& \text { 16 ممود يونس، المرجع السابق، ص. }
\end{aligned}
$$

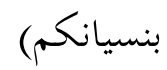

- لا تختلفوا بعد ما عرفتم عاقبة الاختلاف

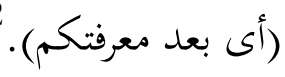

د. لو المصدرية أن تكون ها فوائد عديدة، منها: seandainya - التمنى، بمعنى Seandainya / kiranya Sekiranya مثلا: - ربما يود الذين كفروا لو كانوا - ود كثير من مسلمين أهل الكتاب لو يردونكم - الشرطية بمعنى "إن" أو jika في اللغة الإندونيسية، نحو: ولو شاء ربك الك الجعل

$$
\text { الناس أمة واحدة. }
$$

هـ. "كىى" أن تكون بمنزلة "أن المصدرية" معنى 13 وعمله

مثلا: لكيلا تأسوا على معملا. فاتلى فاتكم ولا تفرحون بما آتاكم وقد تكون "كى مئل للتعليل من حيث هي بمعنى لام الجر، ويكون الفعل

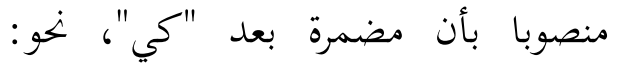
جئت كى أعرف الخبر (أى لمعرفتى الخبر).

$$
\begin{aligned}
& 12 \text { محمد الأمير المالكى المصرى، مغنى اللبيب، }
\end{aligned}
$$

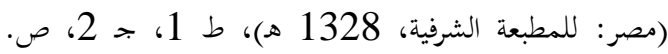

$$
\begin{aligned}
& 194
\end{aligned}
$$




\section{قد سبق لنا أن المعنى الأول}

kata penghubung anak يفيد (bahwa) kalimat والمعانى الثلاثة الأخيرة (bahwasanya,

sesungguhnya, bahwa sesungkata penghubung antar تفيد guhnya) kalimat

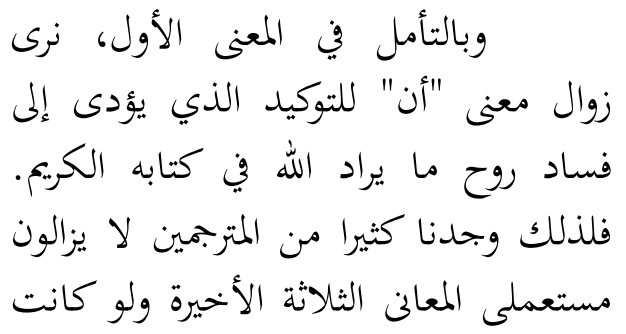

$$
\begin{aligned}
& \text { 2. الاختلاوف في معنى "أن" }
\end{aligned}
$$

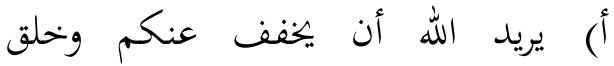

$$
\begin{aligned}
& \text { الإنسان ضعيفا (الأعراف 7: 123: } \\
& \text { قال محمود يونس: }
\end{aligned}
$$

"Allah menghendaki supaya meringankan bagimu (peraturan agama), karena manusia itu dijadikan dalam keadaan lemah. $^{21}$

$$
\text { وقيل في "القرآن وترجمته": }
$$

"Allah hendak memberikan keringanan kepadamu dan manusia dijadikan bersifat lemah."22

$$
\begin{aligned}
& \text { ب) يا أيها النبي قل لأزواجك وبناتك }
\end{aligned}
$$

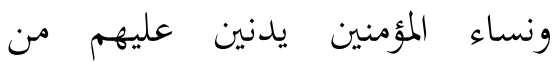

$$
\begin{aligned}
& \text { جلابيبهن. ذلك ادنى أن يعرفن فلاء } \\
& \text { يؤذين ... (الأحزاب 59) } \\
& \text { قيل في "القرآن وترجمته": }
\end{aligned}
$$$$
\text { 21 2حمود يونس، المرجع السابق، ص. } 75
$$

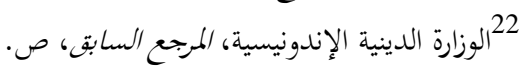

"Tidakkah kamu perhati-kan, bahwa sesungguhnya Allah mengetahui apa yang ada di langit dan apa yang ada di bumi?"17

$$
\begin{aligned}
& \text { ج) قل أوحى إلى أنه استمع نفر من الجن }
\end{aligned}
$$

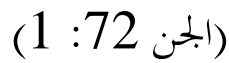

$$
\begin{aligned}
& \text { قال محمود يونس: }
\end{aligned}
$$

"Katakanlah (hai Muham-mad):

"Telah diwahyukan kepadaku bahwa sesung-guhnya serombongan di antara, jin telah men-dengar (Qur'an)..."

$$
\text { وقيل في "القرآن وترجمته": }
$$

"Katakanlah (hai Muham-mad):

"Telah diwahyukan kepadaku bahwasanya telah mendengarkan sekumpulan, $19_{19}$ jin (akan AlQur'an)...."1

$$
\text { باللغة الإندونيسية": وقيضا في "القرآن الكريم المترجم }
$$

"Katakanlah (Muhammad), "Telah diwahyukan kepa-daku, sesungguhnya seke-lompok jin telah mende-ngarkan (AlQur'an)...”20

إذا تأملنا معنى "أن المصدرية أعلاه لرأينا فيه اختلافا بين المترجمين وهي قداديا

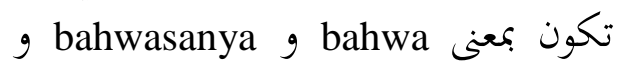
bahwa g sesungguhnya sesungguhnya

$$
19 \text { 19 19 19 الوزارة الدينية الإندونيسية، المرجع السابق، ص. }
$$

القرآن الكريم المترجم باللغة 20 الإندونيسية، (جاكرتا: Sari Agung، 1995)، ط 9، ص. 
"Dan Kami sungguh-sungguh mengetahui, bahwa dadamu menjadi sempit disebabkan apa yang mereka ucapkan". ${ }^{25}$

$$
\text { قال محمود يونس: }
$$

"Sesungguhnya Kami mengetahui, bahwa dada engkau sesak, sebab perkataan mereka itu". ${ }^{26}$

$$
\begin{aligned}
& \text { ب) "...إنى كفرت بما أشركتمونى من } \\
& \text { قبل...." (إبراهيم 14: 22: } \\
& \text { قال محمود يونس: قإنسي }
\end{aligned}
$$

"Sesungguhnya aku ingkar akan apa yang kamu persekutukan dengan daku masa dahulu...,27

تأمل ما قاله المترجمون في الآيتين

السابقتين، تجد اضطرابا بالمعنى لحرف "ماف فماله

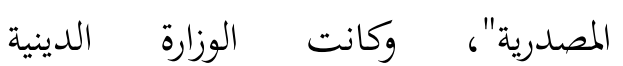

الإندونيسية تقابل كلمة apa لما، وكان ولمدان

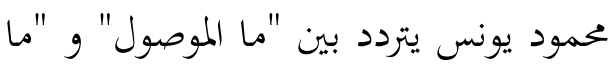

المصدرية"؟ فالجحواب ان ليس فيهما فرق من ين من فين

حيث اللفظ والمعنى. إذن اختلاف المترجمين

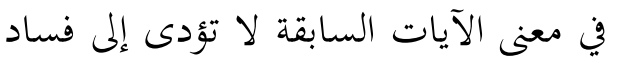

ما يراد به الله تعالى في القرآن الكريم.

4. الاختلاف في معنى "لو"

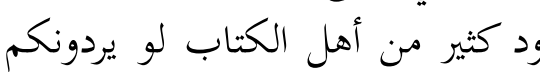

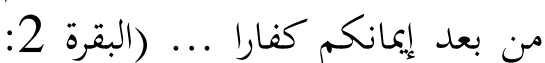

(109

$$
\text { قال محمود يونس: }
$$

"Kebanyakan ahli kitab bercitacita, supaya mereka

$$
\begin{aligned}
& \text { 25 الوزارة الدينية الإندونيسية، المرجع السابق، ص. } \\
& 26 \text { 2حمود يونس، المرجع السابق، ص. } 241 \\
& 27 \text { نفس المرجع ، ص. } 233
\end{aligned}
$$

399
"Hai Nabi, katakanlah kepada istri-istrimu, anak-anak perempuanmu, dan istri-istri orangorang muk-min: Hen-daklah mereka mengulurkan jilbabnya ke seluruh tubuh mereka. Yang demikian itu supaya mereka lebih mudah untuk dikenal, karena itu mereka tidak diganggu...." ${ }^{23}$

$$
\begin{aligned}
& \text { ج) إن الله يأمركم أن تؤدوا الأمانات إلى }
\end{aligned}
$$

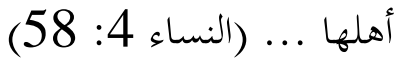

$$
\begin{aligned}
& \text { قال محمود يونس: }
\end{aligned}
$$

"Sesungguhnya Allah menyuruhmu supaya kamu membayarkan amanat kepa-da yang empunya, .".24

تكلمنا فيما مضى أن لأن

المصدرية معنى كمثل أن المصدرية إلا أهما

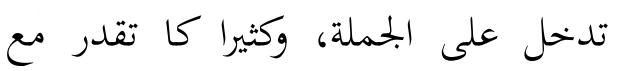

الفعل وإنما كانت وظيفتها لجمالة، وكيرا أن تغير تركيب

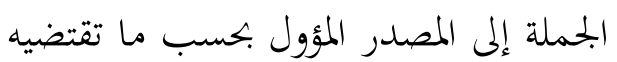<smiles>[AlH2][AsH2]</smiles>

وإذا رجعنا إلى معنى "أن" للآيات

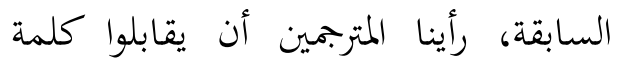

غ supaya g untuk غير شاذ لأن ما يراد به كان لمناسبة سياق

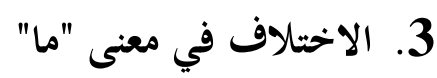

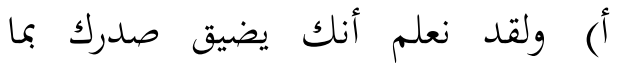

$$
\text { يقولون (الحجر 15: 97 9قآنمان }
$$

$$
\text { قيل في "القرآن وترجمته" }
$$

$$
\begin{aligned}
& 876 \text { 23 } 876 \\
& \text { 24 ممود يونس، المرجع السابق، ص. صن. } 79
\end{aligned}
$$


- من ميترجم "لو" بتقديرها مع الفعل. وأما استعمال كلمة: agar/supaya

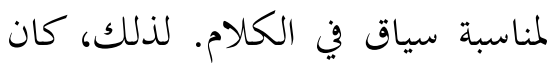
الاختلاف لا تؤدى إلى فساد المعنى.

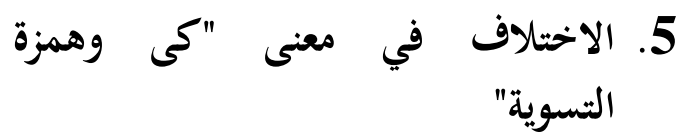

ما رأينا اختلافا بين المترجمين في

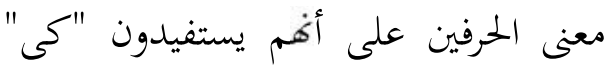
للتعليل وهمزة التسوية للمقدرة. مثلا:

- وأشركه في أمرى كى نسبحك كثيرا (ط) 33-32: 20

قال محمود يونس:

"Dan jadikanlah dia serikatmu dalam urusanku, supaya kami banyak bertasbih" 33

$$
\text { وقيل في "القرآن وترجمته": }
$$

"Dan jadikanlah dia sekutu dalam urusanku, agar kami banyak bertasbih kepada Engkau...."34

$$
\begin{aligned}
& \text { - . . - سواء عليهم أنذرغم أم لم تنذرهم }
\end{aligned}
$$

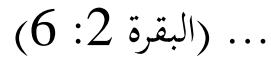

$$
\begin{aligned}
& \text { قال محمود يونس: (لبعرد }
\end{aligned}
$$

“.... Sama bagi mereka, engkau beri peringatan mereka atau tidak kami beri peringatan".,35

$$
\begin{aligned}
& \text { وقيل في "القرآن وترجمته": } \\
& \text { 33 } 33 \text { ممود يونس، المرجع السابق، ص. } 283
\end{aligned}
$$

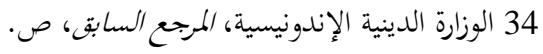

$$
\begin{aligned}
& \text { 35ممود يونس، المرجع السابق، ص. } 4
\end{aligned}
$$

mengembalikan kamu menjadi kafir..."28

$$
\text { قال زين الدين الحميدى وفخرالدين: }
$$

"Kebanyakan dari orang-orang keturunan Kitab ingin kiranya mereka dapat mengembalikan kamu menjadi kafir..."29

$$
\text { وقيل في "القرآن وترجمته": }
$$

"Sebagian besar Ahli Kitab menginginkan agar mereka dapat mengembalikan ka-mu kepada kekafiran..."30

$$
\begin{aligned}
& \text { ب) ربما يود الذين كفروا لو كانوا مسلمين }
\end{aligned}
$$

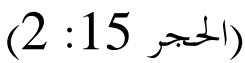

$$
\begin{aligned}
& \text { قال زين الدين الحميدى وفخرالدين: }
\end{aligned}
$$

"Kadang-kadang orang-orang yang tidak beriman itu ingin, kalau mereka menjadi orangorang Islam..."31

$$
\text { قال: - - - - ( }
$$

"seringkali orang yang kafir menyesali diri, sekiranyalah mereka menjadi orang muslim,"32

وبا لتأمل إلى ترجمة الآيتين

$$
\text { السابقتين رأينا المترجمين قسمين: }
$$

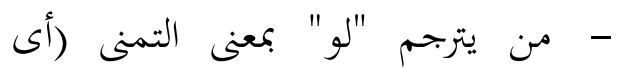
باستخدام كلمة: kalau و و و و .sekiranyalah

$$
\begin{aligned}
& 28 \text { نغس المرجع ، ص. } 16 \\
& 29 \text { زين الدين حمدى وفخر الدين، تغسير القرآن، } \\
& \text { جاكرتا: وجاوى، 1990)، ط 14، ص. } 23
\end{aligned}
$$

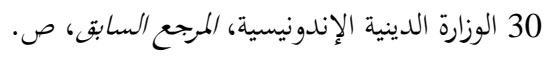

$$
\begin{aligned}
& 31 \text { زين الدين حمدى، المرجع السابق، ص. } 326 \\
& { }^{32} \text { HB Jassin, Bacaan Mulia, Jakarta: }
\end{aligned}
$$

Jamabatan, 1991), hal. 352 
“....sama saja bagi mereka, kamu beri peringatan atau tidak kamu beri peringatan....,36

ومما أسبقت في هذه المقالة، فالآن

سأقدم الخلاصة من هذا البحث كما يأتى:

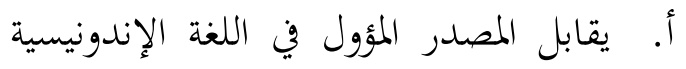

klausa sematan

Noun clause

ب. قد اختلف مترجموا القرآن الكريم في مقابلة

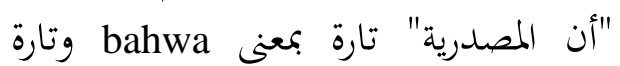

أخرى بمعنى: bahwasanya

bahwa g sesungguhnya

. sesungguhnya

أكثرهم يترجموفا بالمعنى الثانى

خوفا لفساد روح ما يراد به الله تعالى في بكريا

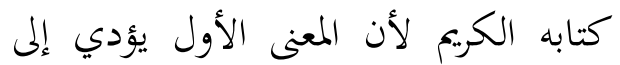

سقوط معنى "أن" للتوكيد. لان المعين

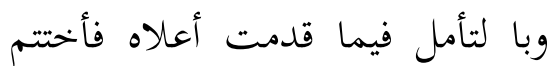

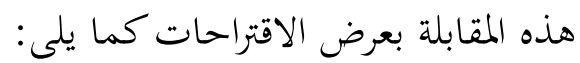

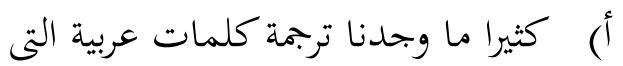

تخالف القواعد الإندونيسية الصحيحة.

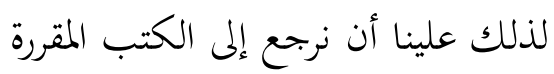

التي أخرجتها الحلكومة.

ب) علينا أن نشجع نفوسنا على دراسة الحتحة

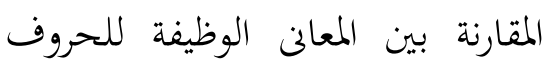

ومقابلتها في اللغة الإندونيسية.

36 الوزارة الدينية الإندونيسية، المرجع السابق، ص. 
Krishnaswamy, Modern English: A Book of Grammar, Usage and Composition, India: The Masmillian Co, 1978

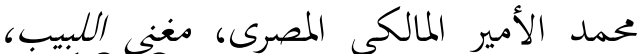
مصر : للمطبعة الشرفية، المصن مغنح 1328 هـ

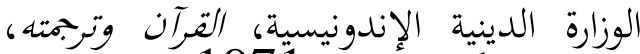

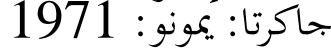

Tim Disbintalad باللغة الإندونيسية، جاكرتا: 1995 ،Agung زين الدين حمدى وفخر الدين، تنسير القرآن، 1990

HB Jassin, Bacaan Mulia, Jakarta: Jambatan, 1991

\section{المراجع}

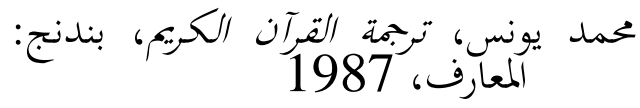

Hamka

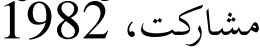

Departemen Pendidikan dan

Kebudayaan RI, Tata Bahasa

Baku Bahasa Indonesia, Jakarta: Balai Pustaka, 1988), hal. 237

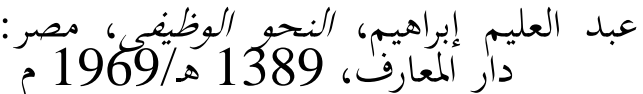

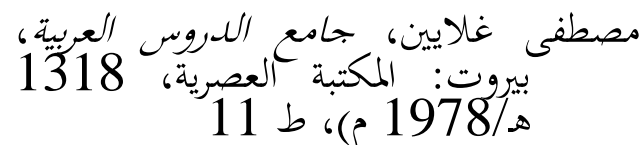

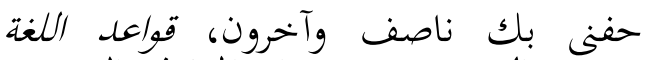
العربية، مصر : ورارة المعارف العمومية 